\title{
ПРИЕМ В ГРАЖДАНСТВО ЛИЦ, ПРОЖИВАЮЩИХ ЗА РУБЕЖОМ: ПОЛИТИКА РОССИИ И МЕЖДУНАРОДНЫЙ ОПЫТ
}

\author{
ОКСАНА ХАРАЕВА, ОЛЬГА ЧУДИНОВСКИХ
}

\begin{abstract}
В статье обсуждаются вопросы приема в гражданство Российской Федераџии лиц, проживающих за пределами страны. В контексте мирового опыта Российская практика является одной из наиболее масштабных и демонстрирует тенденции $\kappa$ расиирению. Политические права, делегируемые лицам, не живущим в стране получаемого гражданства, несут в себе определенные риски влияния на политические процессы в самой стране. Экономические гарантии для новых граждан выполняются за счет работающего населения этой страны и других ее ресурсов, а сами новые граждане не участвуют в формировании сочиильных фондов. Авторы делают вывод о том, что последние решения об упрощении приема в российское гражданство жителей юго-восточных областей Украины (без условия переезда в Россию) потенциально могут иметь ощутимые для населения России экономические и политические последствия, которые пока в полной мере трудно прогнозировать. Мировой опыт проведения политики взаимодействия с «соотечественниками» $u$ диаспорой неоднозначен. Он показывает, что страны, осуществляющие прием в гражданство или предоставляющие преференции соотечественникам, живущим за их пределами, не используют гражданство как единственный инструмент. Они вводят систему статусов, предоставляя одни права и ограничивающие другие, устанавливая временные рамки действия подобньх программ. Авторы приходят к заключению, что в настоящее время подходы к предоставлению гражданства России лицам, проживающим за ее пределами, нуждаются в пересмотре, потому что сохраняющаяся практика и ее масштабы не вполне отвечают интересам населения России.
\end{abstract}

Ключевые слова: гражданство, натурализация, миграция, соотечественники, диаспора.

\section{ВВЕДЕНИЕ}

Традиционно порядок приобретения гражданства рассматривается как один из важнейших элементов или инструментов миграционной политики. Большинство мигрантов, меняя страну постоянного жительства, имеют планы в дальнейшем стать ее гражданами и полноправными членами принимающего сообщества. Для таких мигрантов расширяются экономические возможности в форме свободного допуска на рынок труда страны проживания, полноценного включения в систему социального страхования, права заниматься видами деятельности, недоступными иностранцам (такими как государственная служба, работа в правоохранительных структурах и др.).

ОКСАНА АЛЬФРЕДОВНА ХАРАЕВА (oхa-na1@yandex.ru), МОСКОВСКИЙ ГОСУДАРСТВЕННЫЙ УНИВЕРСИТЕТ им. М.В. ЛОМОНОСОВА, РОССИЯ.

ОЛЬГА СЕРГЕЕВНА ЧУДИНОВСКИХ (migrstat@yandex.ru), МОСКОВСКИЙ ГОСУДАРСТВЕННЫЙ УНИВЕРСИТЕТ им. М.В. ЛомоносовА, Россия.

СТАТЬЯ ПОДГОТОВЛЕНА В РАМКАХ ИССЛЕДОВАНИЯ, ВЫПОЛНЕННОГО ПРИ ПОДДЕРЖКЕ РФФИ, ГРАНТ №19-О10-О0670 "ОЦЕНКА РЕЗУЛЬТАТОВ РЕАЛИЗАЦИИ МИГРАЦИОННОЙ ПОЛИТИКИ РОССИЙСКОЙ ФЕДЕРАЦИИ И ПРЕДЛОЖЕНИЯ ПО ЕЁ МОДЕРНИЗАЦИИ В НОВЫХ ЭКОНОМИЧЕСКИХ И ГЕОПОЛИТИЧЕСКИХ УСЛОВИЯХ".

СТАТЬЯ ПОСТУПИЛА В РЕДАКЦИЮ В СЕНТЯБРЕ 2019 Г. 
Кроме того, эти люди приобретают все права на участие в политической жизни своей новой родины, в том числе право голосовать на выборах и быть избранными в органы управления на разных уровнях. Дети натурализованных мигрантов вливаются в население и часто ничем не отличаются от своих сверстников, не имеющих «миграционного происхождения». Работая и проживая в этой стране, мигранты и их потомки вносят вклад в ее экономическое и политическое развитие, формируют ее настоящее и будущее.

Литература по вопросам миграции и натурализации чрезвычайно обширна и затрагивает широкий спектр сюжетов, таких как изменение взглядов государства на политику натурализации, условия получения гражданства, влияние этого фактора на социальную и экономическую интеграцию мигрантов и так далее. Получение гражданства считается в большинстве случаев одним из этапов миграционного процесса, по сути - его завершающей фазой. Поэтому последствия натурализации рассматриваются лишь в контексте последствий миграции в целом. Значительно реже изучается вопрос приема в гражданство людей, которые не живут в стране получаемого гражданства и, возможно, даже не планируют переезд в обозримой перспективе. Имеющиеся работы (на которые мы будем ссылаться ниже) отражают практику отдельных, немногочисленных государств. Между тем этот вопрос имеет большое значение, поскольку показывает, как институт гражданства может использоваться странами для продвижения их интересов за рубежом и в то же время влиять на экономические и политические процессы внутри страны даже вне связи с иммиграцией.

В предлагаемой статье мы рассматриваем политику Российской Федерации в отношении приема в гражданство лиц, проживающих за ее границами, и сравниваем российскую ситуацию с практикой ряда зарубежных государств. Мы попытаемся ответить на вопросы о масштабах явления, его политических и экономических аспектах как с позиций новых граждан, так и стран, предоставивших свое гражданство ${ }^{1}$.

\section{ПРЕДОСТАВЛЕНИЕ РОССИЙСКОГО ГРАЖДАНСТВА ЗА ПРЕДЕЛАМИ РОССИИ ПОСЛЕ РАСПАДА СССР}

Прием в российское гражданство лиц, живущих за пределами России, и без условия переезда не является новым явлением. Такая возможность была предусмотрена еще первым законом «О гражданстве РСФСР», ставшим после распада СССР и изменения названия нашей страны законом «О гражданстве Российской Федерации» ${ }^{2}$. По закону жители бывших советских республик по желанию могли обратиться в российское консульство и получить гражданство просто «в порядке регистрации». В первые годы после распада СССР, в особых исторических условиях 1990-х годов, широкая практика рассмотрения заявлений о приеме в гражданство вне пределов России была оправданной. После распада СССР гражданство жителей республик определялось «механически» по месту постоянной прописки (Аксенов 2011: 62), что не устроило очень многих. Сотни тысяч жителей бывших

\footnotetext{
${ }^{1}$ В статье мы не рассматриваем вопросы оформления гражданства детям, родители которых живут за пределами своей родины, сохраняя ее гражданство.

2 Закон РФ "О гражданстве Российской Федерации" от 28 ноября 1991 г. №1948-1. 
союзных республик, волею судьбы оказавшихся за рубежами России и не захотевших получить гражданство республики своего проживания (а точнее - прописки ${ }^{3}$ ), смогли быстро оформить гражданство России в порядке регистрации в консульствах России ${ }^{4}$. Это помогло им при переезде в Россию избежать проблем с регистрацией и сделать процесс переезда не столь трудным, как для многих вынужденных мигрантов 90-х годов.

Однако уже в конце 1990-х годов политическая обстановка на пространстве бывшего СССР изменилась. Другими стал состав миграционных потоков, их причины. Пересмотр подходов к регулированию миграции к приобретению гражданства Российской Федерации обусловил принятие в 2002 г. двух важнейших законов: первого в истории постсоветской России закона «О правовом положении иностранных граждан» ${ }^{5}$, и нового закона «О гражданстве Российской Федерации» ${ }^{6}$.

В первой редакции Закона о гражданстве 2002 г. законодатели попытались сделать процесс приема в гражданство РФ не таким простым и формальным, как прежде. Однако особенности постсоветской миграционной обстановки в РФ потребовали внесения поправок, снова расширивших практику упрощенного приема в гражданство ${ }^{7}$. После этого селективность, заложенная в первой редакции закона 2002 г., по сути дела, была сведена на нет. В последующие годы законодательство в отношении натурализации лиц, уже переехавших в Россию, изменялось преимущественно в сторону упрощения процедур и сокращения сроков ожидания. По данным ФМС/ГУВМ МВД России, за десятилетний период с 2009 по 2018 г. в гражданство через органы ФМС/МВД были приняты более 2 млн иммигрантов, из них в общем порядке (предполагающим не менее шести лет проживания в России) всего $0,07 \%$, в упрощенном и по международным соглашениям (оба варианта предполагают короткие сроки ожидания) - 82 и 14\% соответственно. Около $3 \%$ приобрели гражданство по иным основаниям ${ }^{8}$.

Многочисленные поправки к закону о гражданстве 2002 г. практически не затронули приема в гражданство через загранучреждения России 9 . В настоящее время приобрести

\footnotetext{
${ }^{3}$ Специальный доклад Уполномоченного по правам человека в Российской Федерации от 6 декабря 2007 г. «О практике изъятия российских паспортов у бывших граждан СССР, переселившихся в Российскую Федерацию из стран СНГ» (2008). Российская Газета, 26 января, Федеральный выпуск №4573. URL: http://www.rg.ru/2008/01/26/pasporta-doklad.html

4 Эта норма действовала до 31 декабря 2000 г.

5 Федеральный закон "О правовом положении иностранных граждан в Российской Федерации" от 25 июля 2002 г. №115-Ф3.

${ }^{6}$ Федеральный закон "О гражданстве Российской Федерации" от 31 мая 2002 г. №62-Ф3.

${ }^{7}$ В первую очередь, речь идет о значительных контингентах мигрантов, прибывших в Россию в предыдущие годы (в основном - 1990-е) с паспортами СССР образца 1974 г., военнослужащих, проходивших службу в вооруженных силах России и не имевших в этой связи паспортов, а также некоторых других категориях населения, оказавшихся без гражданства РФ после принятия нового закона. Внесение поправок было инициировано обращением Государственной Думы к Президенту России (См. Постановление от 11 апреля 2003 г. №3873-III ГД Об обращении Государственной думы Федерального Собрания Российской Федерации «К Президенту Российской Федерации В. Путину о ситуации, сложившейся после принятия Федерального закона «О гражданстве Российской Федерации»).

${ }_{8}^{8}$ В частности, в рамках урегулирования правового статуса отдельных категорий лиц, находящихся на территории Российской Федерации (см. Главу VIII.1 Закона о гражданстве).

${ }^{9}$ Единственным изменением, имевшим «усложняющий» характер, было введенное условие получения гражданства РФ выпускниками российских вузов. Начиная с 2014 г., заявление о приеме в гражданство
} 
гражданство через консульства могут лица, имеющие хотя бы одного из родителей, состоящего в российском гражданстве и проживающего на территории России, а также лица без гражданства - бывшие граждане СССР, проживающие на территории государств, входивших в его состав. Особую категорию составляют несовершеннолетние дети, которым российское гражданство может быть оформлено по заявлению их родителей (усыновителей, опекунов), имеющих гражданство РФ $\Phi^{10}$.

Таблица 1. Распределение лиц, получивших гражданство Российской Федерации через загранучреждения России по странам проживания и периодам, 2003-2017 гг. ${ }^{11}$

\begin{tabular}{|c|c|c|c|c|}
\hline \multirow{2}{*}{$\begin{array}{l}\text { Страна } \\
\text { проживания } \\
\text { соискателя }\end{array}$} & \multirow{2}{*}{$\begin{array}{c}\text { Получили гражданство } \\
\text { в 2003-2017 гг. } \\
\text { Всего, тыс. }\end{array}$} & \multicolumn{2}{|c|}{ В том числе, по периодам, тыс. } & \multirow{2}{*}{$\begin{array}{c}\text { Доля жителей* } \\
\text { отдельных стран } \\
\text { (2003-2017), \% }\end{array}$} \\
\hline & & 2003-2009 & 2010-2017 & \\
\hline Всего & 720,3 & 374,4 & 345,9 & 100 \\
\hline Армения & 15,0 & 3,0 & 12,0 & 2,1 \\
\hline Германия & 37,8 & 19,3 & 18,5 & 5,3 \\
\hline Казахстан & 20,6 & 8,2 & 12,4 & 2,9 \\
\hline Киргизия & 31,7 & 10,8 & 20,9 & 4,4 \\
\hline Латвия & 37,1 & 16,2 & 20,9 & 5,2 \\
\hline Молдавия & 186,5 & 110,7 & 75,8 & 25,9 \\
\hline США & 23,8 & 11,8 & 12,0 & 3,3 \\
\hline Таджикистан & 49,7 & 15,7 & 34,0 & 6,9 \\
\hline Узбекистан & 31,6 & 20,2 & 11,4 & 4,4 \\
\hline Украина & 19,9 & 8,9 & 11,0 & 2,8 \\
\hline Другие страны & 266,6 & 149,6 & 117,0 & 37,0 \\
\hline
\end{tabular}

Источник: Консульский департамент МИД России (КД МИД).

Примечание: * - В статистике КД МИД указывается не гражданство соискателя, а страна (и город) нахождения загранучреждения, куда было подано заявление о приеме в гражданство.

За весь постсоветский период через загранучреждения Российской Федерации гражданство было предоставлено почти 2,4 млн человек. Из них 1,7 млн получили гражданство в период с 1992 по 2002 г., 374,4 тыс. - с 2003 по 2009 г. и еще более 400 тыс. - с 2010 по 2018 г. В некоторые годы (1992-1994) число решений о приеме в гражданство, оформленных через консульства, значительно превышало показатели МВД России. В последние годы ежегодно российское гражданство через консульства приобретают около 50 тыс. человек. Распределение лиц, получивших гражданство через загранучреждения в период с 2003 по 2017 г., показало, что более четверти из них проживали на территории Молдавии, что объясняется достаточно просто. Речь идет о гражданах непризнанной Приднестровской Молдавской Республики, которым российское гражданство широко

подается ими только на территории России и при наличии трехлетнего стажа работы по востребованной в РФ специальности.

${ }^{10}$ См. сайт Консульского департамента МИД России, раздел «Консульские функции за рубежом» / Вопросы гражданства. URL: https://www.kdmid.ru/cons.aspx

${ }^{11}$ Данные МИД за ряд лет (2007-2008 и 2010-2011) были предоставлены без выделения категории детей, которым гражданство было оформлено по факту рождения или усыновления гражданином России. В среднем, по имеющимся данным, их доля составляла около $25 \%$ в общем числе произведенных процедур по предоставлению или оформлению гражданства. В 2018 г. число лиц, принятых в гражданство, и детей, которым гражданство было оформлено по рождению или усыновлению, составило 49,7 и 16,2 тыс. человек соответственно. Данные за 2018 г. были предоставлены без распределения по странам. 
предоставлялось и предоставляется. В 2007 г. их доля в общем потоке достигла 48\% (таблица 1).

По нашему убеждению, сохранение канала масштабного приема в гражданство России лиц, проживающих за ее пределами, привело к консервации практики, пока не приносящей видимой пользы России и ее населению. Если человек остается жить за рубежом, наша страна не получает ни нового человеческого капитала, ни рабочих рук, но при этом выполняет свои обязательства по обеспечению материальной, социальной (и не только) поддержки своих новых граждан.

Надо отметить, что практически невозможно проследить миграционные траектории этих людей. В 1990-е и начале 2000-х годов в большинстве случаев за получением гражданства следовал переезд в Россию. Но в настоящее время имеет место иная тенденция: получив гражданство (и сопутствующие этому политические и экономические права), новые граждане России остаются в своих странах.

\section{НОВЕЛЛЫ В СФЕРЕ ПРИОБРЕТЕНИЯ РОССИЙСКОГО ГРАЖДАНСТВА ЗА ПРЕДЕЛАМИ РОССИИ}

Основные проблемы, которые мы связываем с практикой приема в гражданство лиц, живущих за рубежом, были освещены одним из авторов этой статьи в двух работах прошлых лет. В числе выводов была отмечена необходимость сужения такой практики как несоответствующей интересам населения России (Чудиновских 2014; 2018). Необходимость снова обратиться к этой теме и рассмотреть ее уже в международном контексте, обусловлена недавними решениями по приему в российское гражданство населения юго-восточных областей Украины.

В конце 2018 г. был принят Закон (от 27 декабря 2018 г. №544-Ф3), дающий право Президенту РФ «в гуманитарных целях определять категории иностранных граждан и лиц без гражданства, имеющих право обратиться с заявлениями о приеме в гражданство Российской Федерации в упрощенном порядке» ${ }^{12}$. Пояснительная записка к закону, оставшаяся вне зоны общественного внимания, открывает истинный замысел декабрьского закона, который может существенно изменить смысл института российского гражданства и механизмы его действия. В ней сказано, что новая норма позволит принять в гражданство РФ в упрощенном порядке соотечественников, «проживающих в странах со сложной общественно-политической и экономической обстановкой, где происходят вооруженные конфликты и (или) смена политического режима». Нетрудно заметить, что понимание «сложности» обстановки зависит от субъективных взглядов интерпретаторов закона и правоприменителей, а признаки такой обстановки можно отыскать во многих государствах постсоветского (и не только) пространства. В сочетании с крайне широким определением «соотечественников» потенциальные масштабы применения этой нормы становятся непредсказуемыми.

12 Федеральный закон "О внесении изменений в Федеральный закон "О гражданстве Российской Федерации" от 27 декабря 2018 г. №544-Ф3. 
На основании этого закона уже в конце апреля 2019 г. Президентом были подписаны указы, в которых шла речь об упрощенном порядке приема в российское гражданство населения юго-восточных областей Украины и отдельных категорий иностранных граждан и лиц без гражданства. Первый указ, упростивший прием в российское гражданство жителей самопровозглашенных Донецкой и Луганской Народных Республик, был подписан 29 апреля 2019 г. ${ }^{13}$ Через несколько дней еще один указ распространил упрощенный порядок обращения за российским гражданством на некоторые категории граждан стран дальнего зарубежья (Афганистана, Сирии, Ирака), а также уроженцев Крыма, впоследствии выехавших на жительство в другие регионы или страны ${ }^{14}$. Уже после подписания первого указа можно было предугадать, что Донецкая и Луганская Республики не останутся единственными в списке территорий юго-восточных регионов Украины, где будет упрощено получение российского гражданства. В июле 2019 г. такой порядок был распространен на все население Донецкой и Луганской областей ${ }^{15}$. Эти решения вызывали определенный резонанс в России и за рубежом не только особым местом украинской тематики в современной повестке России, но и потенциально большими масштабами применения новых норм. По существующим оценкам Комитета по статистике Украины, численность населения Донецкой и Луганской областей превышает 6 млн человек ${ }^{16}$, и в теории все они могут претендовать на российское гражданство. Впервые за многие годы

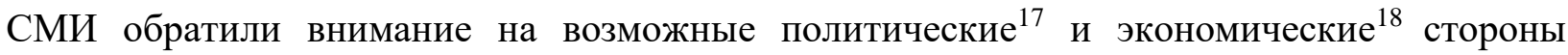
вопроса предоставления российского гражданства людям, живущим за пределами страны.

\section{ПОЛИТИЧЕСКИЕ И ЭКОНОМИЧЕСКИЕ ПОСЛЕДСТВИЯ ПРИЕМА В ГРАЖДАНСТВО ЖИТЕЛЕЙ ЗАРУБЕЖНЫХ СТРАН}

Политические аспекты приема в гражданство жителей зарубежных стран очевидны. Они выражаются, во-первых, в формировании электората, который не участвует лично в социальной или экономической жизни страны своего гражданства. Человеческий капитал этих избирателей не прибавляется к капиталу населения страны, а дети «зарубежных»

\footnotetext{
13 Указ Президента РФ от 24 апреля 2019 г. №183 "Об определении в гуманитарных целях категорий лиц, имеющих право обратиться с заявлениями о приеме в гражданство Российской Федерации в упрощенном порядке".

14 Указ Президента РФ от 29 апреля 2019 г. №187 (ред. от 17.07.2019) "Об отдельных категориях иностранных граждан и лиц без гражданства, имеющих право обратиться с заявлениями о приеме в гражданство Российской Федерации в упрощенном порядке".

15 Указ Президента Российской Федерации от 17 июля 2019 г. № 343 "О внесении изменений в Указ Президента Российской Федерации от 29 апреля 2019 г. № 187 "Об отдельных категориях иностранных граждан и лиц без гражданства, имеющих право обратиться с заявлениями о приеме в гражданство Российской Федерации в упрощенном порядке".

${ }^{16}$ По оценке на 1 июня 2019 г. население Донецкой области составляло 4151526 человек, Луганской - 2145 310 человек. URL: http://database.ukrcensus.gov.ua/PXWEB2007/eng/news/op_popul_e.asp

17 Аптекарь П. (2019). Чем опасна российская паспортная экспансия. Ведомости, 25 апреля. URL: https://www.vedomosti.ru/opinion/articles/2019/04/25/800119-opasna-pasportnaya-ekspansiya; Putin Simplifies Russian Citizenship Process for Eastern Ukrainians (2019). The Moscow Times, April 24. URL: https://www.themoscowtimes.com/2019/04/24/putin-simplifies-russian-citizenship-process-for-eastern-ukrainiansa65372; McKridy E. (2019). Putin offers Russian citizenship to Ukrainians in separatist-held areas. CNN, April 25. URL: https://edition.cnn.com/2019/04/25/europe/putin-ukraine-russian-citizenship-offer-intl/index.html 18 Паспортизация Донбасса обойдется России в \$2 млрд в год? (2019). Новые Известия, 25 апреля. URL: https://newizv.ru/article/general/25-04-2019/pasportizatsiya-donbassa-oboydetsya-rossii-v-2-mlrd-v-god
} 
граждан России не помогают решению задач демографического развития. При этом, реализуя право голоса, такие избиратели могут определять судьбу населения страны своего гражданства (часто - не единственного). Причем этот «внешний» электорат, как показывает мировая практика, может быть как консервативным (что более вероятно в случае паспортизации жителей зарубежных стран и предоставления им определенных выгод), так и в большей степени настроенным на перемены (это более характерно для эмигрантов, покинувших страну из-за неудовлетворенности политическим и экономическим положением).

Второй аспект связан с тем, что, по мнению ряда авторов, «систематическое распространение гражданства на постсоветском пространстве» - это проявление экспансионистской политики России в этом регионе. Отдельное внимание уделяется политике паспортизации населения непризнанных республик. Отмечается, что в каждой стране практика паспортизации имела свои особенности, но главным мотивом была возможность вмешательства под предлогом защиты граждан России, в особенности, если их контингент значителен (Nagashima 2017: 2; Lohr 2012: 181-182).

Отметим, что в странах, предоставляющих политические права лицам, живущим за рубежом, влияние внешнего гражданства на избирательные процессы вызывает особую озабоченность. Основным аргументом в пользу предоставления прав голоса таким гражданам являлась необходимость обеспечения равенства гарантируемых конституцией прав всех граждан вне зависимости от места их проживания (Low 2018). Однако внешние избирательные права могут стать инструментом внутриполитической борьбы, а голосование электората за рубежом способно оказать решающее влияние на результаты национальных выборов, как это произошло в Италии в 2006 г. (Faist, Gerdes 2008: 6) ${ }^{19}$. При этом избиратели-нерезиденты фактически не испытывают последствий своих политических решений. То же самое показал опыт Венгрии (см. ниже). В этой связи политика массового предоставления гражданства соотечественникам и их потомкам за рубежом вызывает неудовольствие в странах, предоставивших этим людям гражданство без условия переезда. Раздача паспортов, в особенности в государствах с компактным проживанием этнических меньшинств, рассматривается в качестве формирования условий для выдвижения территориальных претензий. Двойное гражданство и специальные документы иностранных государств, формализующие иную идентичность, во многих случаях оцениваются как угроза национальной безопасности, даже если речь не идет о пересмотре государственных границ. Считается, что граждане с расщепленной лояльностью могут лоббировать интересы других стран. В связи с этим, к примеру, в Белоруссии депутатам Национального собрания запрещено пользоваться картой поляка ${ }^{20}$.

Политические риски или возможность расширения влияния России привлекают внимание чаще, чем негативные экономические последствия этой ситуации для самой

\footnotetext{
${ }^{19}$ В 2006 г., впервые в истории страны, граждане Италии, проживающие за рубежом, могли проголосовать, находясь в своих странах (по почте, без приезда в Италию). Участие в голосовании «зарубежных» граждан повлияло на итоги выборов, в итоге партия Берлускони потерпела поражение (Chiarmonte 2008: 208).

${ }^{20}$ Мельничук Т. (2017). Половина «карт поляка» в мире выдана в Беларуси. BBC News-Pyсcкая служба, 19 августа. URL: https://www.bbc.com/russian/features-40971103
} 
России, и в этом дисбалансе внимания прослеживается определенный парадокс. На наш взгляд, политические риски являются таковыми в потенциале (даже процесс участия в российских выборах трудно предсказать, учитывая низкую электоральную активность населения). В то же время реальными являются растущие финансовые расходы России на выполнение обязательств перед своими гражданами вне зависимости от способа и времени получения гражданства или места проживания (и к этим вопросам новые граждане отнюдь не безразличны).

Так, например, статистика Пенсионного фонда России при всей ее неполноте ${ }^{21}$ красноречиво иллюстрирует последствия массового приема в гражданство России лиц, не проживающих и, скорее всего, никогда не работавших в нашей стране. В таблице 2 приведены данные о числе лиц, получающих Российские пенсии за границей.

Таблица 2. Численность получателей российской пенсии, проживающих за границей, 2015-2018 гг., тыс.

\begin{tabular}{l|r|r|r|r|c}
\hline & 2015 & 2016 & 2017 & 2018 & $\begin{array}{c}\text { на 26 августа } \\
2019 \text { г. }\end{array}$ \\
\hline ИТОГО & & & & 329,7 & 335,0 \\
Германия & 288,7 & 296,6 & 307,0 & 99,0 & 98,1 \\
Израиль & 99,9 & 100,6 & 101,4 & 51,4 & 56,3 \\
Абхазия & 41,1 & 40,8 & 41,4 & 32,7 & 32,7 \\
Латвия & 32,0 & 32,6 & 32,9 & 23,1 & 23,2 \\
Белоруссия & 24,1 & 25,4 & 24,6 & 24,7 & 25,0 \\
США & 20,9 & 23,2 & 24,3 & 21,7 & 21,4 \\
Молдавия & 22,0 & 21,9 & 21,8 & $\mathrm{H} /$ д & 39,7 \\
Прочие & 16,5 & 17,3 & н / д & 72,8 & 38,5 \\
\hline
\end{tabular}

Источник: (Пенсионный фонд РФ 2017; 2018), 2015-2016 и 2019 г2. - «Открытые данные». URL: http://www.pfrf.ru/opendata 7706016118-abroad

Первые позиции Германии и Израиля в таблице объяснимы: это страны самой массовой эмиграции из России в дальнее зарубежье в 1990-е годы. Люди, проработавшие значительную часть жизни в России, имеют право получать российскую пенсию. Но Абхазия $^{22}$ и Молдавия никогда не входили в число основных направлений выезда

\footnotetext{
${ }^{21}$ Мы предполагаем, что данные о числе лиц, проживающих за рубежом и получающих российские пенсии, отражает только видимую часть айсберга. Распространены практики получения пенсий в России родственниками пенсионеров, которые проживают за границей, не декларирование выбытия за рубеж и др. Более точную картину влияния приема в гражданство на распределение российских пенсий за рубежом могла бы дать статистика оснований для назначения пенсий, в том числе с выделением лиц, оформляющих пенсию после приобретения гражданства. Но в ответе Пенсионного фонда на наш запрос сказано, что по закону право на страховую пенсию граждан РФ не зависит от их места жительства, а выплата уже назначенных пенсий не зависит от гражданской принадлежности, за исключением положений международных договоров, и поэтому данные, которые мы запрашивали, в ПФР отсутствуют «как не имеющие практического применения».

${ }^{22}$ В отношении Абхазии Россия несет дополнительные расходы в рамках двух соглашений: см., например, «Соглашение между Российской Федерацией и Республикой Абхазия о пенсионном обеспечении граждан Российской Федерации, постоянно проживающих в Республике Абхазия» от 14 апреля 2014 г., а также «Соглашение между Российской Федерацией и Республикой Абхазия о порядке и условиях софинансирования за счет средств Российской Федерации повышения заработной платы основных категорий работников государственных учреждений Республики Абхазия в сфере здравоохранения, образования, науки, культуры, спорта и социального обслуживания» (Распоряжение Правительства от 3 апреля 2015 г. №591-p). Аналогичные соглашения заключены с Южной Осетией. Доплаты производятся до уровня Южного Федерального округа.
} 
российского населения на постоянное место жительства (ПМЖ) за рубеж. В данном случае мы наблюдаем последствия приема в гражданство жителей этих регионов и стран через загранучреждения Российской Федерации с последующим оформлением пенсий, которые в этих государствах имеют неплохую покупательную способность или служат весомым дополнением к другим доходам. В конце 2018 г. выплаты Пенсионного фонда России получали пенсионеры, проживающие в 128 странах мира, их численность достигла 329,7 тыс. человек, увеличившись по сравнению с 2017 г. на 22,7 тыс. или 7,5\%. Расходы ПФР на выплату пенсий за границу в 2018 г. составили 44,7 млрд рублей, что было почти на 8\% выше уровня 2017 г. (Пенсионный фонд РФ 2017; 2018). К сожалению, статистика за 2017-2018 гг. в открытых данных по странам отсутствует, а в годовом отчете ПФР она представлена лишь по нескольким государствам и в форме гистограммы.

После принятия в гражданство целевых категорий граждан Украины число получателей российских пенсий может вырасти приблизительно на миллион человек, соответственно увеличатся и общие выплаты. На пенсии жителям Украины может потребоваться еще минимум 100 млрд рублей в год. Кроме того, новые гражданки России получат право на материнский капитал, который, заметим, был придуман как средство для стимулирования рождаемости и поддержки семей с детьми в России, а не в других странах. Условие переезда в Россию (а точнее - регистрации) для получения материнского капитала не может служить большим препятствием к тому, чтобы потом вернуться на Украину. За годы действия программы отработаны разные схемы «обналичивания» и использования этих средств. Также следует обратить внимание на высказывание сенатора С. Цекова о том, что он допускает вариант, при котором жители Донбасса с российским гражданством смогут получать социальные выплаты, не покидая территории своих непризнанных республик ${ }^{23}$.

Апрельский указ о приеме в гражданство жителей ЛНР и ДНР вызвал вопросы к представителям органов власти, но ответы показывают отсутствие четкого видения того, как будет развиваться ситуация на практике. Министр труда и социальной защиты Российской Федерации М. Топилин, отвечая на вопрос журналистов о назначении пенсий жителям ЛНР и ДНР, сказал, что это потребует (по его мнению) регистрации на территории России $^{24}$. Такое предположение представляется нелогичным: непонятно, почему в отношении этой части новых граждан будут применяться требования, которые не применяются в отношении жителей других стран, которым Россия предоставляет свое гражданство. Мы полагаем, что, даже если новым соискателям российского гражданства для получения пенсии гипотетически будет предписано зарегистрироваться на территории РФ (а этого не требует современное законодательство о пенсиях), вероятнее всего, они останутся жить там, где у них есть жилье, земельные участки, хозяйство, налаженные социальные связи. Оформление регистрации на территории России, как показывает

${ }^{23}$ В Совфеде рассказали о возможностях, которые дадут жителям Донбасса паспорта РФ. URL: https://riafan.ru/1176879-v-sovfede-rasskazali-o-vozmozhnostyakh-kotorye-dadut-zhitelyam-donbassa-pasporta-rf ${ }^{24}$ Минтруд назвал условие получения жителями Донбасса российской пенсии (2019). РИА Новости, 13 мая. URL: https://ria.ru/20190513/1553437632.html 
многолетний опыт, не является препятствием к тому, чтобы постоянно проживать в другой стране.

Также М. Топилин отметил, что «выплата пенсий для новых граждан не станет проблемой для российского бюджета, бюджетов Пенсионного фонда и Фонда социального страхования». Но это утверждение находится в противоречии с аргументами прошлогодней информационной кампании, сопровождавшей решение о повышении пенсионного возраста. В условиях, когда прогнозируется дефицит средств на выплаты «своим» пенсионерам, которые принимали участие в формировании перечисленных М. Топилиным бюджетов, министр фактически говорит, что мы «без проблем» сможем обеспечить пенсиями еще как минимум миллион новых пенсионеров, к формированию российских фондов не причастных. По-видимому, именно из-за слишком очевидных противоречий между аргументацией пенсионной реформы 2018 г. и перспективами новых расходов тема паспортизации населения ЛНР/ДНР очень слабо освещалась в СМИ и быстро исчезла из медийного пространства.

Заметим, что у принятых весной и летом 2019 г. решений есть много сторонников, но при ближайшем рассмотрении видно, что они тоже не вполне понимают перспективы развития ситуации. Часто встречается заявление о необходимости «пустить всех русских в Россию», предоставив им гражданство еще до переезда. Авторы такой точки зрения не чувствуют разницы между миграцией и получением российского паспорта. Например, М. Симоньян (главный редактор известного государственного медиаресурса Russia Today) в своем блоге горячо приветствовала подписание Указа от 29 апреля 2019 г. и выразила желание добиться для всех русских права на наше гражданство 25 . Однако, судя по дальнейшим рассуждениям о том, что Россия нуждается в мигрантах - не мусульманах (видимо, православных христианах), автор блога не понимает, что прием в гражданство и миграция не тождественны ${ }^{26}$. М. Симоньян полагает, что все, получившие российские паспорта, непременно приедут в Россию, чтобы стать частью ее населения и трудовых ресурсов. Но практика показывает, что этого, вероятнее всего, не произойдет. Нет никаких гарантий, что новые граждане России в массовом порядке захотят переселиться из Донецкой и Луганской областей Украины в Россию. Часть из них, вероятно, будут рассматривать и этот миграционный маршрут, но он не будет единственным, учитывая возможности, которые дает гражданство Украины в других странах мира и налаженные каналы миграции (пусть даже и временной) в страны ЕС. Не будем забывать, что Россия уже несет на себе бремя финансовых обязательств перед десятками тысяч своих новых граждан, получивших российские паспорта за рубежом и там же остающихся без видимого стремления приехать в Россию и содействовать ее развитию.

\footnotetext{
${ }^{25}$ URL: https://m-simonyan.livejournal.com/360100.html

${ }^{26}$ Вызывает неприятие и призыв М. Симоньян «выбить из всех несогласных (с приемом в российское гражданство жителей Донбасса, О.Ч.) все их аргументы, почему этого делать не надо» (там же). 


\section{ЗАРУБЕЖНАЯ ПРАКТИКА ПРИЕМА В ГРАЖДАНСТВО ЛИЦ, ПРОЖИВАЮЩИХ ЗА ГРАНИЦЕЙ}

После подписания Указа от 29 апреля 2019 г. Президент Российской Федерации В.В. Путин, комментируя сообщение о негативной реакции за рубежом на решение по паспортизации Донбасса, сказал следующее: «...Это вызвало какую-то негативную реакцию? Это странно, что решения подобного рода у кого-то вызывают негативную реакцию. Польша уже в течение многих лет выдает карту поляка, Венгрия и Румыния выдают паспорта. Когда другие страны - соседи Украины в течение многих лет это делают, почему Россия не может этого делать? В этой связи у меня возникает вопрос: а чем же русские, проживающие на Украине, хуже румын, поляков или венгров? Или украинцы, проживающие там же, но чувствующие свою неразрывную связь с Россией в силу разных обстоятельств родственных связей, смешанных браков и каких-то других. Я здесь не вижу ничего необычного ${ }^{27}$. На самом деле зарубежная практика дает весьма неоднозначные ответы на вопрос о том, положительным или нет (для страны и ее населения) является опыт приема в гражданство людей, живущих за рубежом. С этой точки зрения сравнение Российской ситуации с зарубежными примерами представляет большой интерес.

Многие страны (преимущественно отдающие мигрантов), в последнее время применяют целый комплекс мер, которые можно назвать «стратегией взаимодействия с диаспорой». Это подразумевает лояльность к двойному гражданству эмигрантов, предоставление им прав на участие в выборах, поощрение денежных переводов и инвестиций (Kalm 2013: 18-19). Возможность обращения иностранных граждан с ходатайством о приеме в гражданство через загранучреждения предусмотрена законодательством некоторых стран, реализующих, в первую очередь, меры по укреплению связей с эмигрантским сообществом, к которому относятся не только эмигранты первого поколения, но и их потомки, представители диаспоры в широком смысле слова. Обеспечивая этим людям защиту, права и признание, страны происхождения надеются на их поддержку и взаимодействие в экономической, культурной и политической областях. В ряде случаев страны исхода вводят ограничения на осуществление некоторых гражданских и экономических прав, а также предлагают представителям диаспоры некоторый вариант «облегченного гражданства» (Faist, Gerdes 2008: 7).

В законодательстве многих европейских стран - «старых» членов Евросоюза также содержатся положения, в той или иной мере способствующие приему в гражданство жителей (и граждан) определенных стран или лиц этнически близкого происхождения (Bauböck 2006b). Однако лишь немногие государства (например, Ирландия, Греция, Испания, Португалия) предоставляют гражданство на основании культурного родства иностранным гражданам, проживающим за рубежом. Здесь важно проводить различие между политикой, которая преследует понятные интересы посылающих стран в поддержании связей с эмигрантами, и массовым предоставлением внешнего гражданства

${ }^{27}$ В. Путин (2019). Чем русские, проживающие на Украине, хуже румын, поляков или венгров? BFM.RU, 25 апреля. URL: https://www.bfm.ru/news/412831 
бывшим гражданам и их потомкам, негативно влияющим на интересы других групп населения и государств (Bauböck et al. 2006a).

В этой связи критическую оценку (González Enríquez 2014) вызвали законодательные инициативы правительства Испании, введенные с целью исправления исторической несправедливости (законы «Об исторической памяти» $(2007$ г.) и «Гражданство для сефардских евреев» (2015)).

Согласно Закону «Об исторической памяти», гражданство Испании смогли получить дети и внуки испанцев, покинувших страну в годы Гражданской войны (1936-1939 гг.) и последующего диктаторского режима (1939-1975 гг.), в знак признания несправедливости изгнания ${ }^{28}$. Заявления принимались в течение трех лет с 27 декабря 2008 г. по 26 декабря 2011 г. Было подано 503 тыс. прошений, главным образом, от граждан стран Латинской Америки. Около 300 тыс. было удовлетворено (González Enríquez 2014). Количество поданных заявлений превзошло ожидания испанских властей (Sánchez, Cuesta 2017). Интерес, проявленный эмигрантами и их потомками к регистрации в консульствах, не в последнюю очередь был мотивирован ожиданиями финансовой помощи от правительства Испании. Например, в 2013 г. социальные выплаты испанским гражданам старше 80 лет на Кубе составили в среднем 227 евро - достаточно значительная сумма в стране, где среднемесячная заработная плата в этот период колебалась от 20 до 40 евро (Sánchez, Cuesta 2017).

Закон в отношении потомков сефардов, изгнанных из Испании в XV веке, также давал возможность получить испанское гражданство без условия обязательного проживания в Испании и без отказа от уже имеющегося гражданства ${ }^{29}$. Закон действовал в течение четырех лет, за первые три года гражданство получили более 6 тыс. человек ${ }^{30}$. Следует отметить, что введение упрощенного порядка натурализации для сефардских евреев породили ожидания и протесты в среде другого крупного сообщества, изгнанного из Испании и Португалии, - мавров ${ }^{31}$.

В публикациях, посвященных вопросам политики в области гражданства, отмечается, что предложение гражданства без условия переезда и проживания, превращая представителей коренных меньшинств в иностранных граждан, может иметь серьезные последствия для стабильности отношений между странами и положения этнических групп в принимающих обществах (Bauböck et al. 2006a). Реализация данного подхода в таких странах, как Испания, Португалия, Греция, также подвергается критике, поскольку это формирует значительный контингент лиц за пределами ЕС, имеющих право въезда,

\footnotetext{
${ }^{28}$ Ministry of Justice of Spain. Descendants of Spanish nationals. URL: https://leymemoria.mjusticia.gob.es/cs/Satellite/LeyMemoria/en/concesion-nacionalidad/descendientes-espanoles ${ }^{29}$ Ministry of Justice of Spain. Ley de concesión de nacionalidad a sefardíes originarios de España.

URL: https://www.mjusticia.gob.es/cs/Satellite/Portal/en/areas-tematicas/nacionalidad/concesion-nacionalidad

${ }^{30}$ Spain extends citizenship law for Sephardic Jews (2018). The Times of Israel, 9 March.

URL: https:/www.timesofisrael.com/spain-extends-citizenship-law-for-sephardic-jews/

${ }^{31}$ If Spain welcomes back its Jews, will its Muslims be next? (2014). The Guardian, February 24.

URL: https:/www.theguardian.com/world/2014/feb/24/spain-sephardic-jews-islam-muslim;

Kern S. (2012). Muslims Angry Over Spanish Citizenship for Jews. Gatestone Institute, December 21.

URL: https://www.gatestoneinstitute.org/3509/spanish-citizenship-jews
} 
пребывания и трудоустройства на территории любой из стран Европейского Союза (González Enríquez 2014).

Стремлением к исправлению исторической несправедливости были продиктованы и изменения в законодательстве о гражданстве ряда восточноевропейских стран. Особенности формирования государственности в странах Восточной Европы определили появление значительных по численности этнических групп, оказавшихся за пределами своих стран. Большинство государств региона признает свои обязательство по защите родственных меньшинств, проживающих за рубежом, а также поддерживает идеи трансграничного объединения народов, вводя специальные привилегии для представителей родственных этнических меньшинств в соседних странах. Ряд государств, среди которых Венгрия, Румыния, Хорватия, Сербия и Болгария, постепенно пришли к установлению института внешнего гражданства, отменив требования к месту проживания, что, в сочетании с предоставлением прав на получение гражданства потомкам бывших граждан, значительно увеличило численность потенциальных и действительных граждан этих стран за рубежом (Pogonyi, Kovács, Körtvélyesi 2010). В некоторых случаях вступление в гражданство на основе этнокультурной принадлежности стало основным каналом его приобретения (например, в Румынии и Венгрии) (Dumbrava 2014).

В Венгрии упрощенная процедура предоставления гражданства (без требований обязательного проживания на территории страны и при сохранении существующего гражданства) была введена после принятия поправок к закону о гражданстве в мае 2010 г. (Pogonyi 2013). Вновь установленные правила касались лиц, способных документально подтвердить наличие венгерского гражданства у родственников по прямой восходящей линии или имеющих основания утверждать свое вероятное венгерское происхождение (данная формулировка появилась в тексте закона, чтобы не лишать возможности обращения с ходатайством проживающих в Румынии и Молдавии представителей венгерского субэтноса чангош, редко обладающих документальными свидетельствами своего происхождения) $)^{32}$. Необходимыми условиями участия в программе являются знание венгерского языка, отсутствие судимости, а также каких-либо обстоятельств, представляющих угрозу общественной и национальной безопасности ${ }^{33}$. Срок рассмотрения заявления составляет 4-5 месяцев с момента его представления ${ }^{34}$. С января 2011 г. по сентябрь 2013 г. более 500 тыс. человек обратились за получением венгерского гражданства в рамках данной программы (из них 66\% составляли румынские граждане, $18 \%$ - сербские и 13\% - граждане Украины) и более 430 тыс. человек принесли присягу на верность Венгрии (Monostori, Öri, Spéder 2015: 194). Это число достигло 500 тыс. человек к декабрю 2013 г. и 670 тыс. к февралю 2015 г. (Monostori, Öri, Spéder 2015: 195). Наибольший интерес к венгерскому гражданству среди соседних стран проявили в не входящих в ЕС Украине и

\footnotetext{
${ }^{32}$ Материалы официального сайта программы упрощенной натурализации правительства Венгрии. URL: http://allampolgarsag.gov.hu/index.php?option=com_content\&view=category\&id=27\&Itemid=65 ${ }^{33}$ Office of the President of the Republic. Hungarian citizenship. URL: https://www.keh.hu/hungarian_citizenship/1583-Citizenship_cases\&pnr=2; Материалы официального сайта программы упрощенной натурализации. URL: http://allampolgarsag.gov.hu/images/angol.pdf ${ }^{34}$ Материалы официального сайта программы упрощенной натурализации правительства Венгрии. URL: http://allampolgarsag.gov.hu/index.php?option=com_content\&view=article\&id=96:mennyi-ideig-tart-azeljaras\&catid=27:kerelmezok\&Itemid=65
} 
Сербии, 96 и 60\% соответственно венгерского населения которых к июлю 2016 г. представили заявления о вступлении в гражданство. В Румынии доля венгров, ходатайствующих о гражданстве, составила $40 \%$, в Словакии - лишь $0,6 \%$, что объяснялось введенным в 2010 г. в ответ на действия Венгрии запретом на двойное гражданство (лица, добровольно вступившие в гражданство другого государств, автоматически лишались гражданства Словакии) (Pogonyi 2019).

Вслед за либерализацией правил предоставления гражданства венгерское правительство внесло изменения в электоральное законодательство. Новый закон о выборах, вступивший в силу 1 января 2012 г., установил право на участие в парламентских выборах граждан, проживающих за рубежом ${ }^{35}$. Считается, что именно поддержка диаспоры обеспечила правящей партии дополнительный мандат, необходимый для получения абсолютного большинства в парламенте, на выборах 2014 г. (Pogonyi 2015). Законодательство Венгрии признает за гражданами, проживающим за рубежом, также пассивные избирательные права, возможность участвовать в референдумах, а также (с 2019 г.) в выборах в Европейский парламент ${ }^{36}$.

По мнению венгерского исследователя С. Погоньи (Pogonyi 2015), введение в Венгрии института внешнего гражданства и предоставление избирательных прав гражданам, проживающим за рубежом, не было мотивировано геополитическими или экономическими целями, но служило идее символического национального воссоединения. При этом активный подход к утверждению прав венгерских меньшинств привел к обострению межгосударственных отношений Венгрии с Румынией, Словакией и Украиной. Как отмечает С. Погоньи: «Новая политика правительства Венгрии в отношении диаспоры не отвечает интересам страны. Поток ресурсов в этой системе является однонаправленным» (Pogonyi 2015: 91).

В Румынии поправки в закон о гражданстве, упрощающие процедуру приобретения гражданства и расширяющие основания его получения, были введены в 2009 г. (Iordachi 2010: 18). Согласно новым правилам, гражданство Румынии может быть предоставлено лицам, родившимся с 1918 по 1940 г. на территории Молдавии, Северной Буковины (современной Черновицкой область Украины), Бессарабии (юго-западной части Одесской области Украины), а также их детям и внукам ${ }^{37}$. Условия программы не предусматривают обязательного собеседования на румынском языке (Iordachi 2009). От претендентов на получение гражданства требуется лишь документальное подтверждение факта рождения хотя бы одного из предков на территориях, входивших в состав Румынии до 1940 г. Этническая принадлежность заявителя не принимается во внимание ${ }^{38}$. Также не требуется отказ от имеющегося гражданства и проживание в Румынии. Срок рассмотрения заявлений

\footnotetext{
35 Joint Opinion on the Act on the Elections of Members of Parlement of Hungary, 662/2012, adopted by Council for Democratic Elections at its 41st meetings (Venice, 14 June 2012) and the Venice Commission at its Plenary Session (Venice, 15-16 June 2012). URL:

https://www.venice.coe.int/webforms/documents/default.aspx?pdffile=CDL-AD(2012)012-e

${ }^{36}$ National Election Office of Hungary. URL: https://www.valasztas.hu/web/national-election-office/votersregistration.

37 Посольство Румынии в РФ. Румынское гражданство. URL: https://moscova.mae.ro/ru/node/1149

${ }^{38}$ Dobran C. (2011). Romanian citizenship. A Simplified Regime for Moral Reparation. POLITICO, August 31. URL: https://www.politico.eu/article/romanian-citizenship/
} 
по упрощенной процедуре приобретения гражданства ограничивается пятью месяцами. За период с 2010 по 2017 г. на уровне Национального органа по вопросам гражданства было утверждено 499,9 тыс. заявлений о восстановлении румынского гражданства ${ }^{39}$. Румынские граждане-нерезиденты пользуются правом голоса на парламентских выборах и национальных референдумах (Varga 2019). Право на социальные выплаты (пенсии и пособия) в Румынии предоставляется на основании не только гражданства, но также постоянного проживания в стране. Получила распространение практика оформления молдавскими гражданами с румынскими паспортами формальной регистрации на территории Румынии, открывающей доступ к системе социального обеспечения, в частности к получению пенсий (в 2018 г. средний размер пенсий в Румынии составлял 232 евро, в Молдавии - 83,4 евро ${ }^{40}$ ). Обязательства Румынии по выплате пенсий гражданам, не участвовавшим в свое время в формировании румынского пенсионного фонда, вытекают из сохранившего силу Соглашения между СССР и Румынской Народной Республикой о сотрудничестве в области социального обеспечения от 24 декабря 1960 г., согласно которому при изменении места жительства права на получение пенсии переводятся из одной страны в другую.

Политика внешнего гражданства Румынии была негативно воспринята в соседних странах. Украина и Молдавия обвинили Румынию в ревизионизме (Iordachi 2010: 13). Правительство Молдавии ввело визы для румынских граждан, несмотря на соглашение с ЕС о безвизовом режиме для граждан стран Евросоюза ${ }^{41}$. В 2007 г. после вступления Румынии в ЕС Молдавия ввела запрет на замещение государственных должностей лицам с двойным гражданством (отмененный в 2010 г. по решению Европейского суда по правам человека). Украина, не допускающая двойного гражданства, оценила действия Румынии в отношении этнических меньшинств на своей территории как угрозу национальной безопасности (Iwanski 2011). Подавляющее большинство лиц, получивших гражданство Румынии по упрощенной процедуре, рассматривает его как инструмент, позволяющий им обойти визовые ограничения ЕС, и переезжает в другую страну Евросоюза сразу при получении румынского паспорта (Dumbrava 2019).

Польша. В своем комментарии, процитированном выше, В.В. Путин упомянул карту поляка. Однако карта поляка - документ, подтверждающий принадлежность к польскому народу $^{42}$, не предполагает одновременного приема в гражданство, а лишь упрощает его получение по прошествии нескольких лет, и этот пример заметно отличается от российской практики. Условиями получения карты поляка является наличие этнических поляков (или лиц с польским гражданством) среди родственников по прямой восходящей линии, знание польского языка, традиций и обычаев страны, а также подписание декларации о

\footnotetext{
39 Чрезвычайное постановление Правительства Румынии «О внесении изменений и дополнений в Закон о румынском гражданстве» №21/1991. Официальный монитор Румынии. Часть 1, №760/25.IX.2017. URL: https://advokat-romania.ru/blog/izmenenija-v-zakone-o-grazhdanstve-rumynii.html

40 Зарплаты и пенсии в Румынии и в Молдове: сравнительная статистика (2018). Молдавские ведомости, 19 мая. URL: http://www.vedomosti.md/news/zarplaty-i-pensii-v-rumynii-i-v-moldove-sravnitelnaya-statis 41 Лунгеску O. (2009). Евросоюз обеспокоен выдачей молдаванам румынских паспортов. BBC News. Pyccкая служба, 5 мая. URL: https://www.bbc.com/russian/international/2009/05/090504_romania_passport_moldova ${ }^{42}$ Ministry of Foreign Affairs, Republic of Poland. Polish Card. URL: https://www.msz.gov.pl/en/foreign_policy/polish_diaspora/card_of_the_pole/
} 
принадлежности к польскому народу ${ }^{43}$. С вступлением в силу поправок в Закон «О карте поляка», принятых Сеймом Польши в апреле 2019 г., этот документ будет выдаваться гражданам всех стран, имеющим польское происхождение (до этого только гражданам стран бывшего СССР) ${ }^{44}$.

Обладателям карты поляка предоставляются привилегии в форме бесплатного получения долгосрочной многократной визы в Польшу, права на бесплатное обучение, на трудоустройство в стране без разрешения на работу, права на предпринимательскую деятельность на тех же основаниях, что и у граждан Польши, право на получение в неотложных случаях бесплатных медицинских услуг, а также возможность обращения за получением постоянного вида на жительство. Для получения гражданства Польши требуется не менее года прожить в стране по виду на жительство. Кроме того, для держателей карты, переехавших на постоянное место жительства в Польшу, предусмотрена выплата пособия в течение первых 9 месяцев пребывания в стране. По данным демографического ежегодника Польши, за период с 2008 по 2017 г. карту поляка получили всего 234,5 тыс. человек, из них почти 112 тыс. (48\%) были гражданами Белоруссии и 102 тыс. (43\%) - Украины (Statistics Poland 2018: 494). В 2011 г. Конституционный суд Республики Беларусь охарактеризовал Закон «О карте поляка» как затрагивающий интересы Республики Беларусь и нарушающий нормы международного права ${ }^{45}$. С 2012 г. в Белоруссии был введен запрет на пользование картой поляка государственными служащими и депутатами парламента, а в 2015 г. - и депутатами местных советов ${ }^{46}$. В Литве также рассматривали возможность ограничения прав держателей карты поляка, однако Сейм Литвы отклонил поправку о запрете держателям карты поляка избираться в Сейм ${ }^{47}$.

Практика, подобная польской, применяется и в Турции. С 1995 г. для бывших турецких граждан, натурализовавшиеся в Германии, были введены так называемые «розовые карты», предоставлявшие держателям те же права, которыми обладали граждане Турции, за исключением права голоса (Faist 2007: 133). В 2009 г. они были переименованы в «синие карты», но перечень ограничений для их обладателей стал шире, включив также запрет на трудоустройство в государственном секторе ${ }^{48}$.

Израиль. Программа этнической репатриации является основополагающим элементом политики Израиля в области иммиграции и предоставления гражданства. В 2017 г. новым репатриантам была предоставлена возможность получения паспорта гражданина Израиля для международных поездок непосредственно после вступления в

\footnotetext{
${ }^{43}$ Ministry of Foreign Affairs, Republic of Poland. Polish Card.

URL: https://www.msz.gov.pl/en/foreign_policy/polish_diaspora/card_of_the_pole/

${ }^{44}$ Сейм Польши принял поправки к закону о карте поляка. 15 апреля 2019 г.

URL: https://in-poland.com/sejm-polshi-prinjal-popravki-v-zakon-o-karte-poljaka/

45 Конституционный суд Республики Беларусь. Решение Конституционного суда Республики Беларусь от

7 апреля 2011 г. № П-258/2011. URL: http://www.kc.gov.by/main.aspx?guid=23203

46 Усидеть на двух стульях. Нужна ли белорусским чиновникам карта поляка? (2015). NAVINY.BY.

Белорусские новости, 10 марта. URL: https://naviny.by/rubrics/politic/2015/03/10/ic_articles_112_188411

${ }^{47}$ Сейм отклонил предложение обратиться в Конституционный суд по поводу карты поляка (2013).

RU.15MIN.LT, 23 мая. URL: https://www.15min.lt/ru/article/vesti/sejm-otklonil-predlozhenie-obratitsja-v-

konstitutsionnyj-sud-po-povodu-karty-poljaka-504-338334

${ }^{48}$ Office for Turks Abroad and Related Communities (YTB). URL: https://www.ytb.gov.tr/en/foreign-citizens-guide 
гражданство ${ }^{49}$. Срок действия паспорта для новых граждан ограничивается 5 годами ${ }^{50}$. Условием продления документа является постоянное проживание в Израиле.

Статус постоянного жителя является также решающим фактором в вопросе определения прав на получение медицинской помощи и социальной защиты. Пребывание за рубежом не освобождает граждан Израиля от необходимости уплаты взносов. При этом отсутствие в стране более пяти лет лишает израильтян права на медицинское обслуживание и социальную помощь в рамках государственного страхования даже при регулярной оплате взносов ${ }^{51}$.

При получении гражданства по каналам репатриации Израиль не требует отказа от гражданства страны исхода. Однако лица, обладающие гражданством иностранного государства, не могут избираться в парламент Израиля или занимать должности, связанные с обеспечением безопасности. Въезд на территорию страны для лиц с двойным гражданством разрешен только по израильскому паспорту. На всех граждан Израиля, даже в случае, если они имеют другое гражданство и постоянно проживают за рубежом, распространяется Закон о воинской службе. Призыву в Армию Обороны Израиля подлежат также дети граждан Израиля, выехавшие за границу на постоянное место жительства в возрасте до 16 лет $^{52}$.

Один из вопросов, периодически обсуждаемых в израильском обществе, касается предоставления права голоса гражданам-нерезидентам. В настоящее время граждане Израиля, проживающие за рубежом, могут принять участие в голосовании только, если окажутся на территории страны в день выборов ${ }^{53}$. Многочисленные дискуссии и разнообразные предложения, например, дать право определять будущее Израиля только тем, кто несет национальное бремя (среди возможных критериев уплата израильских налогов или владение недвижимостью в Израиле $)^{54}$, пока не привели к принятию какоголибо решения. Противники введения заочного голосования опасаются чрезмерного влияния на израильскую политику граждан-нерезидентов, учитывая сравнительно легкий доступ к гражданству и потенциал еврейской диаспоры, и предрекают «конец сионизма» ${ }^{55}$. Израиль, по-видимому, не предпринимает особых усилий для выстраивания политики в

\footnotetext{
49 Ровно через месяц новые репатрианты будут получать «дарконы» сразу по прибытии в страну (2017).

Вести - Израиль по-русски, 26 июня. URL: https://www.vesty.co.il/articles/0,7340,L-4981200,00.html

${ }^{50}$ Новые правила получения «даркона». Русскоязычная адвокатская коллегия. URL:

https://zakon.co.il/articles/\%D0\%B4\%D0\%B0\%D1\%80\%D0\%BA\%D0\%BE\%D0\%BD-\%D0\%B0-

$\% \mathrm{D} 1 \% 87 \% \mathrm{D} 1 \% 82 \% \mathrm{D} 0 \% \mathrm{BE}-\% \mathrm{D} 0 \% \mathrm{~B} 1 \% \mathrm{D} 1 \% 83 \% \mathrm{D} 0 \% \mathrm{~B} 4 \% \mathrm{D} 0 \% \mathrm{~B} 5 \% \mathrm{D} 1 \% 82-$

$\% \mathrm{D} 1 \% 87 \% \mathrm{D} 0 \% \mathrm{~B} 5 \% \mathrm{D} 1 \% 80 \% \mathrm{D} 0 \% \mathrm{~B} 5 \% \mathrm{D} 0 \% \mathrm{~B} 7-\% \mathrm{D} 0 \% \mathrm{BF} \% \mathrm{D} 1 \% 8 \mathrm{~F} \% \mathrm{D} 1 \% 82 \% \mathrm{D} 1 \% 8 \mathrm{C}-$

$\% \mathrm{D} 0 \% \mathrm{BB} \% \mathrm{D} 0 \% \mathrm{~B} 5 \% \mathrm{D} 1 \% 82 /$

${ }^{51}$ National Insurance Institute of Israel. URL:

https://www.btl.gov.il/English\%20Homepage/Insurance/An\%20Insured\%20Person\%20Residing\%20Abroad/Pages/

Whois.aspx

52 Министерство репатриации и интеграции Израиля. Служба в армии. Иерусалим. 2016.

URL: http://archive.moia.gov.il/Publications/idf_ru.pdf

${ }^{53}$ Israel Ministry of Foreign Affairs. Elections in Israel 2019. URL:

https://mfa.gov.il/MFA/AboutIsrael/State/Democracy/Pages/FAQ-Elections-in-Israel-2019.aspx

${ }^{54}$ Levy A. (2019). Israelis Residing Abroad Deserve Voting Rights. The Jerusalem Post, January 7.

URL: https://www.jpost.com/Opinion/Israelis-residing-abroad-deserve-voting-rights-576634

55 Ашкенази Э. (2019). Могут ли эмигранты решать судьбу Израиля? Мнения - Zahav.ru, 13 марта.

URL: https://mnenia.zahav.ru/articles/11593/mogut_li_emigranti_reshat_sudbu_israel
} 
отношении эмигрантов не только в силу относительно небольших масштабов эмиграции и сохраняющего негативного отношения к ней, но и в результате наличия хорошо налаженных связей с еврейской диаспорой, традиционно используемой Израилем в качестве источника политической и финансовой поддержки (Harpaz, Herzog 2018: 11).

Приведенные примеры из зарубежной практики показали, что предоставление политических и экономических прав людям, не живущим в стране получаемого гражданства, часто противоречит интересам ее населения. По мнению исследователей (Bauböck et al. 2006a), предоставление гражданства лицам, проживающим за рубежом, должно способствовать поддержанию связей с эмигрантами, но в то же время ограничивать притязания на полные гражданские права лиц, родившихся за границей и имеющих отдаленное эмигрантское происхождение, а также тех, кто заинтересован в получении гражданства по экономическим соображениям или ради приобретения свободы перемещения.

\section{ЗАКЛЮЧИТЕЛЬНЫЕ ЗАМЕЧАНИЯ}

Рассмотренные выше сюжеты показали, что российская политика в сфере предоставления гражданства лицам, живущим за границей, демонстрирует отсутствие какого-либо предвидения её возможных последствий для России. И в прошлые годы прием в гражданство лиц, не проживающих в РФ, показывал их преимущественно экономический интерес к российскому гражданству. Расширение этой практики на население, проживающее в юго-восточных регионах Украины, многократно увеличит поток принятых в гражданство и не живущих в России людей. В современных экономических условиях это вряд ли будет способствовать развитию нашей страны. Заявленная гуманитарная цель предполагает создание более комфортных условий, в первую очередь экономических, для широкого круга лиц, без элементов селективности приема в гражданство. Учитывая неспокойную обстановку в регионе, участие части населения в вооруженном конфликте, паспорта РФ смогут получить и лица, имеющие неоднозначный жизненный опыт.

Пока остается без ответа и ряд важных вопросов: например, ограничится ли практика приема в гражданство по гуманитарным соображениям прецедентом ЛНР и ДНР или будет распространяться все шире? В том числе будет ли возможно отказать русскоязычным соискателями из других (кроме Украины) стран бывшего СССР в таких же привилегиях? Какие еще обязательства возьмет на себя Россия в связи с появлением больших контингентов российских граждан, проживающих на территории других государств? Последуют ли за этим договора, аналогичные заключенным с Абхазией и Южной Осетией? Какие обязательства будут (и будут ли) возложены на новых граждан по отношению к России, например, в сфере всеобщей воинской обязанности, участия в формировании социальных фондов и др.? К чему может привести ситуация, при которой значительная часть населения целых регионов зарубежных стран имеет гражданство другого государства? Как будет применяться статья 7 Ф3 «О гражданстве» о защите граждан РФ 
(вне зависимости от места проживания) ${ }^{56}$ ? Как повлияет прием в гражданство значительного контингента избирателей, не живущих в России, на итоги будущих выборов в России? Не станет ли простота получения гражданства жителями Донбасса стимулом для некоторых мигрантов из других стран к переезду в эти регионы, и будет ли учитываться стаж проживания при приеме в гражданство РФ? И в целом можно ли назвать то, что делает Россия, предоставляя свое гражданство лицам, проживающим за ее пределами, политикой взаимодействия с диаспорой или соотечественниками?

Сочувствуя проблемам, с которыми сталкиваются жители Донбасса (и других регионов бывшего СССР со сложной обстановкой), мы вряд ли можем согласиться с тем, что помогать решению подобных проблем нужно только путем быстрого приема в гражданство и за счет населения Российской Федерации. На протяжении ряда лет, по данным Росстата, уровень жизни населения страны снижается, а аргументы, которые сопровождали пенсионную реформу 2018 г., за истекший год не утратили актуальности. В этом смысле вряд ли логичным является масштабное расширение круга лиц, на которых будут распространяться социальные программы и финансовые обязательства России, но не участвующих в формировании фондов, покрывающих связанные с этим расходы.

Мы по-прежнему убеждены, что практика приема в гражданство лиц, не живущих в стране, должна быть максимально сужена до частных случаев и строго определенных категорий населения. Институт гражданства Российской Федерации нуждается в сохранении и повышении своей ценности, а в отношении приема в гражданство иностранцев все-таки требуется селективность. Иногда журналисты, пишущие о миграционной политике России, путают понятия «жители» и «граждане». Так, газета «Коммерсантъ» сообщала, что «в России сформированы структуры, которые займутся привлечением в Россию новых граждан» ${ }^{57}$. На самом деле России нужны новые жители: не только граждане, но и иностранцы, которые на законных основаниях живут, работают в нашей стране и связывают с ней свое будущее. Мотивация приобретения и предоставления российского гражданства жителям сопредельных с Россией государств понятна, но в современных условиях увеличение количества избирателей и получателей российской экономической помощи за рубежами России не вполне отвечает интересам ее населения.

Зарубежный опыт приема в гражданство и взаимодействия с соотечественниками, проживающими за границей, не дает оснований рассматривать такую практику как определенно положительную для страны, предоставляющей свое гражданство иностранцам до их переезда или даже без такого условия. Остро стоят вопросы избирательных и экономических прав «зарубежных» граждан страны. А соображения исторической справедливости или поддержания связей с этнически близкими «диаспорами» не всегда компенсируют очевидные экономические и политические риски. Именно поэтому многие страны применяют систему условий, отодвигающих во времени прием в гражданство «соотечественников», ограничивающих их доступ к социальным благам страны

\footnotetext{
56 Этот аргумент был использован для обоснования участия России в конфликте между Грузией и Южной Осетией в 2008 г.

${ }^{57}$ Соловьев В. (2019). Мигрантополучатели. Сформированы структуры, которые займутся привлечением в Россию новых граждан. Коммерсантъ, 44, 14 марта, 1. URL: https://www.kommersant.ru/doc/3909388
} 
получаемого гражданства, или же устанавливают весьма узкие временные рамки для действия программ такого рода.

Кроме того, сравнение российской практики с опытом зарубежных стран приводит нас к выводу, что предоставление гражданства не должно быть единственным инструментом взаимодействия с соотечественниками или диаспорой в других государствах. В странах, проводящих подобную политику, помимо (или вместо) приема в гражданство применяется система разнообразных статусов, дающих их владельцам некоторые важные права, но одновременно ограничивающих другие. В случае России складывается парадоксальная ситуация: предоставление гражданства рассматривается, по сути, как единственный механизм установления связей с населением других стран, имеющим какое-то отношение к общему советскому или российскому прошлому. Одновременно «новые граждане» получают полный набор экономических и политических прав, оказываясь в несоизмеримо более выгодном положении, чем мигранты, многие годы работающие на территории России и преодолевающие хитросплетения нашего законодательства и правоприменительной практики в сфере миграции и гражданства. Также заметим, что различия в уровне жизни в России и основных странах, где живут новые граждане РФ, дает последним дополнительный экономический дивиденд.

На фоне опыта других стран деятельность России по приему в гражданство населения других государств выглядит намного более масштабной. Ежегодно гражданами России становятся десятки тысяч человек, не проживающих в нашей стране. При этом трудно назвать эту деятельность продуманной и имеющей понятные цели и основания. Поэтому негативные проявления этого процесса могут оказаться небезразличными для российского общества. Нужно учесть лучшие практики и все-таки пересмотреть направление отечественного законотворчества в этой области, ставя на первый план интересы людей, живущих в России.

\section{ЛИТЕРАТУРА}

Аксенов А.Б. (2011). Современные тенденции в международно-правовом регулировании вопросов гражданства в связи с правопреемством государств. М.: Российская академия правосудия.

Пенсионный фонд РФ (2017). Годовой отчет за 2017 г. URL: http://www.pfrf.ru/files/id/press_center/godovoi_otchet/annual_report_2017_1.pdf

Пенсионный фонд РФ (2018). Годовой отчет за 2018 г. URL: http://www.pfrf.ru/press_center/annual_report/

Чудиновских О.С. (2014). О политике и тенденциях приобретения гражданства Российской Федерации в период с 1992 по 2013 г. Демографическое обозрение, 1(3), 65-126. DOI: 10.17323/demreview.v1i3.1810

Чудиновских О.С. (2018). Статистика приобретения гражданства как отражение особенностей миграционной политики России. Вопросы статистики, 25(9), 3-26. URL: https://voprstat.elpub.ru/jour/article/view/751?locale=ru_RU

Bauböck R. (Ed.) (2006b). Acquisition and Loss of Nationality. Policies and Trends in 15 European States. Vol. 2. Country Analyses. Amsterdam: Amsterdam University Press. 
Bauböck R. et al. (Eds.) (2006a). Acquisition and Loss of Nationality. Policies and Trends in 15 European States. Vol. 1. Comparative Analyses. Amsterdam: Amsterdam University Press.

Chiarmonte A. (2008). How Prodi's Unione won by a handful of votes. In J.L. Newell (Ed.), The Italian general election of 2006. Romano Prodi's victory (pp. 203-222). Manchester and New York: Manchester University Press.

Dumbrava C. (2019). The ethno-demographic impact of co-ethnic citizenship in Central and Eastern Europe. Journal of Ethnic and Migration Studies, 45(6), 897-916. URL: https://www.tandfonline.com/doi/full/10.1080/1369183X.2018.1440490

Dumbrava C. (2014). Nationality, Citizenship and Ethno-Cultural Belonging: Preferential Membership Policies in Europe. Houndmills, Basingstoke, Hampshire; New York: Palgrave Macmillan. URL: http://hdl.handle.net/1814/34661

Faist T. (Ed.) (2007). Dual Citizenship in Europe: From Nationhood to Social integration. Aldershot: Ashgate.

Faist T., Gerdes J. (2008). Dual Citizenship in an Age of Mobility. Washington. DC: Migration Policy Institute. URL: https://www.migrationpolicy.org/research/dual-citizenship-agemobility

González Enríquez C. (2014). The price of Spanish and European citizenship. Royal Institute Elcano. ARI 4/2014 - 3/2/2014. URL: https://www.files.ethz.ch/isn/176641/ARI42014_Gonzalez_Enriquez_price_spanish_and_european_citizenship.pdf

Harpaz Y., Herzog B. (2018). Report on Citizenship Law: Israel. RSCAS/GLOBALCIT-CR 2018/2. European University Institute. Badia Fiesolana, San Domenico di Fiesole (FI), Italy. URL:

https://cadmus.eui.eu/bitstream/handle/1814/56024/RSCAS_GLOBALCIT_CR_2018_02.pd f? sequence $=1 \&$ is Allowed $=\mathrm{y}$

Iordachi C. (2009). Romanian Citizenship Offer to Moldovans: Exaggerated Fears in the European Union. EUDO Citizenship Press Release. URL:

https://www.eui.eu/Projects/EUDO/Documents/05-11-EUDO-romania.pdf

Iordachi C. (2010). Report on Romania. Country Report. RSCAS/EUDO-CIT-CR-2010/20.

Badia Fiesolana, San Domenico di Fiesole (FI), Italy. URL: http://eudocitizenship.eu/docs/CountryReports/Romania.pdf

Iwanski T. (2011). Ukraine - Romania: a sustained deadlock. Centre for Eastern Studies. OSW Commentary. 68. URL: https://www.osw.waw.pl/sites/default/files/commentary_68.pdf

Kalm S. (2013). Diaspora Strategies as Technologies of Citizenship. Global Society, 27(3), 379397. DOI: $10.1080 / 13600826.2013 .790787$

Lohr E. (2012). Russian Citizenship. From Empire to Soviet Union. Harvard University Press. Cambridge, Massachusetts, and London, England.

Low C.C. (2018). MyOverseas Vote: liberalism and extraterritorial citizenship. Citizenship Studies, 22(7), 745-768. DOI: 10.1080/13621025.2018.1508416.

Monostori J., Öri P., Spéder Zs. (Eds.) (2015). Demographic Portrait of Hungary 2015. Budapest: Hungarian Demographic Research Institute. URL:

http://demografia.hu/en/publicationsonline/index.php/demographicportrait/issue/view/326

Nagashima T. (2017). Russia's Passportization Policy toward Unrecognized Republics.

Problems of Post-Communism. DOI: 10.1080/10758216.2017.1388182 
Pogonyi S. (2013). Naturalisation Procedures for Immigrants: Hungary. Naturalisation Procedures Report. RSCAS/EUDO-CIT-NP 2013/12. Badia Fiesolana, San Domenico di Fiesole (FI), Italy. URL: https://core.ac.uk/download/pdf/45683860.pdf

Pogonyi S. (2015). Transborder Kin-minority as Symbolic Resource in Hungary. Journal on Ethnopolitics and Minority Issues in Europe, 14(3), 73-98. URL: https://www.ecmi.de/fileadmin/downloads/publications/JEMIE/2015/Pogonyi.pdf

Pogonyi S., Kovács M., Körtvélyesi Z. (2010). The Politics of External Kin-state Citizenship in East Central Europe. Comparative Report. RSCAS/EUDO-CIT-Comp. 2010/6. Badia Fiesolana, San Domenico di Fiesole (FI), Italy. URL: http://eudocitizenship.eu/docs/ECEcompreport.pdf

Pogonyi S. (2019). The Passport as Means of Identity Management: Making and Unmaking Ethnic Boundaries Through Citizenship. Journal of Ethnic and Migration Studies, 45(6), 975- 993. URL: https://www.tandfonline.com/doi/full/10.1080/1369183X.2018.1440493

Sánchez C.A., Cuesta S.G. (2017). Migration and Spanish Citizenship Abroad: Recent Scenarios from the Cuban Context. Mediterranean Journal of Social Sciences, 8(3), 91-98. URL: https://www.mcser.org/journal/index.php/mjss/article/view/9941/0

Statistics Poland (2018). Demographic Yearbook of Poland 2018. Warsaw. URL: https://stat.gov.pl/en/topics/statistical-yearbooks/statistical-yearbooks/demographicyearbook-of-poland-2018,3,12.html

Varga A. (2019). The Right to Vote of Romanian Citizens Living Abroad. Minority Studies, 15, 187-198. URL:

https://www.researchgate.net/publication/333088815_The_Right_to_Vote_of_Romanian_Cit izens_Living_Abroad 


\title{
GRANTING CITIZENSHIP TO PERSONS LIVING ABROAD: RUSSIAN POLICY AND INTERNATIONAL EXPERIENCE
}

\author{
OXANA KHARAEVA, OLGA CHUDINOIVSKIKH
}

\begin{abstract}
The article discusses issues regarding the granting of Russian citizenship to persons living abroad. In the context of international experience, the Russian practice is one of the most large-scale and is showing a tendency to expand. Granting political rights to persons not living in the country of citizenship brings certain risks of influencing the political processes in the country itself. Economic guarantees for the new citizens are provided at the expense of the working population of this country and its other resources, while the new citizens do not participate in the formation of social funds. The authors conclude that the recent decisions to simplify the acquisition of Russian citizenship by residents of the South-Eastern regions of Ukraine (without the requirement to move to Russia) could potentially have tangible economic and political consequences for the population of Russia that are still difficult to predict. The world's experience of the policy of interaction with "compatriots" and the Diaspora is ambiguous. It shows that countries granting citizenship or giving preferences to compatriots living abroad do not use citizenship as the only tool. They implement a system of statuses, granting some rights and limiting others, and setting a time frame for such programs. The authors conclude that at present the approaches to granting Russian citizenship to persons living outside Russia need to be revised, because the continuing practice and its scale do not fully meet the interests of the Russian population.
\end{abstract}

Key words: citizenship, naturalization, migration, compatriots, diaspora.

OXANA KHARAEva (oxa-na1@yandex.ru), Lomonosov Moscow State University, Russia.

Olga Chudinoivskikh (migrstat@yandex.ru), Lomonosov Moscow State University, Russia.

THE ARTICLE IS PREPARED WITHIN THE FRAMEWORK OF THE RESEARCH CARRIED OUT WITH THE SUPPORT OF RFBR, GRANT №19-010-00670 "EVALUATION OF THE RESULTS OF THE MIGRATION POLICY OF THE RUSSIAN FEDERATION AND PROPOSALS FOR ITS MODERNIZATION IN THE NEW ECONOMIC AND GEOPOLITICAL CONDITIONS".

DATE RECEIVED : SEPTEMBER 2019.

\section{REFERENCES}

Aksenov A.B. (2011). Sovremennyye tendentsii v mezhdunarodno-pravovom regulirovanii voprosov grazhdanstva $v$ svyazi s pravopreyemstvom gosudarstv [Current trends in the international legal regulation of citizenship]. Moscow: Rossiyskaya akademiya pravosudiya. (In Russ.).

Bauböck R. (Ed.) (2006b). Acquisition and Loss of Nationality. Policies and Trends in 15 European States. Vol. 2. Country Analyses. Amsterdam: Amsterdam University Press.

Bauböck R. et al. (Eds.) (2006a). Acquisition and Loss of Nationality. Policies and Trends in 15 European States. Vol. 1. Comparative Analyses. Amsterdam: Amsterdam University Press.

Chiarmonte A. (2008). How Prodi's Unione won by a handful of votes. In J.L. Newell (Ed.), The Italian general election of 2006. Romano Prodi's victory (pp. 203-222). Manchester and New York: Manchester University Press. 
Chudinovskikh O.S. (2014). Policies and trends in acquiring citizenship of the Russian Federation in 1992-2013. Demographic Review, 1(3), 65-126. (In Russ.).

DOI: $10.17323 /$ demreview.v1i3.1810

Chudinovskikh O.S. (2018). Statistics on Citizenship Acquisition as a Reflection of the Peculiarities of the Russian Migration Policy. Voprosy statistiki, 25(9), 3-26. (In Russ.). URL: https://voprstat.elpub.ru/jour/article/view/751?locale=ru_RU

Dumbrava C. (2019). The ethno-demographic impact of co-ethnic citizenship in Central and Eastern Europe. Journal of Ethnic and Migration Studies, 45(6), 897-916. URL: https://www.tandfonline.com/doi/full/10.1080/1369183X.2018.1440490

Dumbrava C. (2014). Nationality, Citizenship and Ethno-Cultural Belonging: Preferential Membership Policies in Europe. Houndmills, Basingstoke, Hampshire; New York: Palgrave Macmillan. URL: http://hdl.handle.net/1814/34661

Faist T. (Ed.) (2007). Dual Citizenship in Europe: From Nationhood to Social integration. Aldershot: Ashgate.

Faist T., Gerdes J. (2008). Dual Citizenship in an Age of Mobility. Washington. DC: Migration Policy Institute. URL: https://www.migrationpolicy.org/research/dual-citizenship-agemobility

González Enríquez C. (2014). The price of Spanish and European citizenship. Royal Institute Elcano. ARI 4/2014 - 3/2/2014. URL: https://www.files.ethz.ch/isn/176641/ARI42014_Gonzalez_Enriquez_price_spanish_and_european_citizenship.pdf

Harpaz Y., Herzog B. (2018). Report on Citizenship Law: Israel. RSCAS/GLOBALCIT-CR 2018/2. European University Institute. Badia Fiesolana, San Domenico di Fiesole (FI), Italy. URL:

https://cadmus.eui.eu/bitstream/handle/1814/56024/RSCAS_GLOBALCIT_CR_2018_02.pd $\mathrm{f}$ ? sequence $=1 \&$ isAllowed $=\mathrm{y}$

Iordachi C. (2009). Romanian Citizenship Offer to Moldovans: Exaggerated Fears in the European Union. EUDO Citizenship Press Release. URL: https://www.eui.eu/Projects/EUDO/Documents/05-11-EUDO-romania.pdf

Iordachi C. (2010). Report on Romania. Country Report. RSCAS/EUDO-CIT-CR-2010/20. Badia Fiesolana, San Domenico di Fiesole (FI), Italy. URL: http://eudocitizenship.eu/docs/CountryReports/Romania.pdf

Iwanski T. (2011). Ukraine - Romania: a sustained deadlock. Centre for Eastern Studies. OSW Commentary. 68. URL: https://www.osw.waw.pl/sites/default/files/commentary_68.pdf

Kalm S. (2013). Diaspora Strategies as Technologies of Citizenship. Global Society, 27(3), 379397. DOI: $10.1080 / 13600826.2013 .790787$

Lohr E. (2012). Russian Citizenship. From Empire to Soviet Union. Harvard University Press. Cambridge, Massachusetts, and London, England.

Low C.C. (2018). MyOverseasVote: liberalism and extraterritorial citizenship. Citizenship Studies, 22(7), 745-768. DOI: 10.1080/13621025.2018.1508416.

Monostori J., Öri P., Spéder Zs. (Eds.) (2015). Demographic Portrait of Hungary 2015. Budapest: Hungarian Demographic Research Institute. URL:

http://demografia.hu/en/publicationsonline/index.php/demographicportrait/issue/view/326

Nagashima T. (2017). Russia's Passportization Policy toward Unrecognized Republics. Problems of Post-Communism. doi: 10.1080/10758216.2017.1388182 
Pension Fund of the Russian Federation (2017). Godovoy otchet za 2017 g. [Annual Report 2017]. (In Russ.). URL: http://www.pfrf.ru/files/id/press_center/godovoi_otchet/annual_report_2017_1.pdf

Pension Fund of the Russian Federation (2018). Godovoy otchet za 2018 g. [Annual Report 2018]. (In Russ.). URL: http://www.pfrf.ru/press_center/annual_report/

Pogonyi S. (2013). Naturalisation Procedures for Immigrants: Hungary. Naturalisation Procedures Report. RSCAS/EUDO-CIT-NP 2013/12. Badia Fiesolana, San Domenico di Fiesole (FI), Italy. URL: https://core.ac.uk/download/pdf/45683860.pdf

Pogonyi S. (2015). Transborder Kin-minority as Symbolic Resource in Hungary. Journal on Ethnopolitics and Minority Issues in Europe, 14(3), 73-98. URL:

https://www.ecmi.de/fileadmin/downloads/publications/JEMIE/2015/Pogonyi.pdf

Pogonyi S., Kovács M., Körtvélyesi Z. (2010). The Politics of External Kin-state Citizenship in East Central Europe. Comparative Report. RSCAS/EUDO-CIT-Comp. 2010/6. Badia Fiesolana, San Domenico di Fiesole (FI), Italy. URL: http://eudocitizenship.eu/docs/ECEcompreport.pdf

Pogonyi S. (2019). The Passport as Means of Identity Management: Making and Unmaking Ethnic Boundaries Through Citizenship. Journal of Ethnic and Migration Studies, 45(6), 975- 993. URL: https://www.tandfonline.com/doi/full/10.1080/1369183X.2018.1440493

Sánchez C.A., Cuesta S.G. (2017). Migration and Spanish Citizenship Abroad: Recent Scenarios from the Cuban Context. Mediterranean Journal of Social Sciences, 8(3), 91-98. URL: https://www.mcser.org/journal/index.php/mjss/article/view/9941/0

Statistics Poland (2018). Demographic Yearbook of Poland 2018. Warsaw. URL: https://stat.gov.pl/en/topics/statistical-yearbooks/statistical-yearbooks/demographicyearbook-of-poland-2018,3,12.html

Varga A. (2019). The Right to Vote of Romanian Citizens Living Abroad. Minority Studies, 15, 187-198. URL:

https://www.researchgate.net/publication/333088815_The_Right_to_Vote_of_Romanian_Cit izens_Living_Abroad 